\title{
Patterns of Female Senior Business Leadership in E-Commerce Companies China
}

\author{
Wei Zhou', a , Ke-Chiun Chang ${ }^{2, b^{*}}$ \\ ${ }^{1}$ College of Public Administration and Law, Hunan Agricultural University, Changsha, China \\ ${ }^{2}$ School of Economics and Management, Wuhan University, Wuhan, China \\ azhouw@hunau.edu.cn, bzhouw@whu.edu.cn
}

\begin{abstract}
Keywords: Female senior manager, e-commerce companies, glass ceiling, leadership pattern Abstract. The glass ceiling problem has been a hot topic in research of female senior leadership in companies, especially in e-commerce companies. It has become a worldwide debate of which promote barriers and weakness for female managers are discussed. China has present a sharp rise this year from $25 \%$ to $51 \%$ female senior management position, however, by sampling survey in this study, we found that female senior managers still in a disadvantageous position. This study sampling investigated 200 China listed companies in e-commerce industry to explore the pattern of female senior business leadership. The results in this study reveal that $75 \%$ of sample companies held no more than 3 female senior managers, $97 \%$ of female members in board of directors. By studying patterns of female senior manager leadership, this study provides evidences of status quo of Chinese female senior managers and therefore draws attention to glass ceiling problems at the highest levels within China listed companies.
\end{abstract}

\section{Introduction}

There is increasing number of female senior managers in top management team nowadays. Surveyed by Grant Thornton International Business Report 2013, numbers of women in leadership roles are growing, from $24 \%$ of companies with women in senior management positions globally in 2013 to $21 \%$ in 2012, indicating a 3\% globally increase in the number of female senior manager [1]. In particularly, this report mentioned above has pointed out that China has presented a sharp rise of women in senior management positions, from $25 \%$ in 2013 to $51 \%$ in 2014[1]. This is the most increase rate over the world countries.

Senior managers undertake company decision-making and deal with company develop strategies. It is doubtless that performance of team senior managers is a matter of long-term survival and development. The research of female senior position in company management was initiated from the arising discussion of "glass ceiling", which defined as "the unseen, yet unbreakable barrier that keeps minorities and women from rising to the upper rungs of the corporate ladder, regardless of their qualifications or achievements" [2] and "invisible, implicit but impenetrable barrier which prevents women from reaching senior positions within organizations" [3]. Baxter and Wright empirically studied data from 3 countries and concluded a general gender gap in authority, and here quote, "an impermeable barrier that blocks the vertical mobility of women "[4]. Despite of the sharp rise of female senior positions in China, which strong implying business women become more acceptable by important manage positions, CHU indicates that gender specific issues still largely exist in China, such as family orientation during work and strong subordination to male family members[5].

Female managers have advantageous within their gender feature. Pascall et al. found that female non-executive directors who are active in some so called traditional industries such as mining, chemicals, and aerospace are underrepresented but have relatively better prospects of reaching board of directors in industries such as retailing, telecommunication services and banking etc.[6]

The main objective of this paper is to find out the patterns of female senior business leadership in listed companies China of e-commerce field by analyzing and discussing the distributions of female 
senior position, age, and education background. Thus draw attention to glass ceiling problems at the highest levels within China e-commerce listed companies.

\section{Sample collection}

This study developed a sample investigation of listed companies China in e-commerce industry in 2014 to explore the pattern of female senior business leadership. All the data used in this paper are downloaded from GTA database, which is considered as leading provider of timely, accurate, and comprehensive financial data for China. This database provides general information of senior manage team over 2881 listed companies China. Dropping companies with incomplete information, we applied systematic sampling investigation with $\mathrm{K}$ valued 4 and sampling fraction of $25 \%$. Finally we obtained a set of sample with 200 companies in e-commerce industry. Sample data are processed by SPSS13.0 statistic software.

\section{Findings and Discussion}

In this sampling survey, we set senior managers as a cluster of director, supervisors, and senior managers. Figure 1 shows the distribution of female senior managers cross companies and their average age. $\mathrm{X}$-axis indicates the number of female who is inside the senior management team. There are $12 \%$ companies in this sample with no female senior manager. Companies with only one female senior manager have the largest share of $22.3 \%$, followed by two female with $21.9 \%$ share. As we can see from figure 1, the companies' amount decreases by the increasing number of female senior managers. There is only one company holds 10 female senior managers in the sampling survey. Average age of each female senior managers group is with no exception between ages of 40 to 50 .

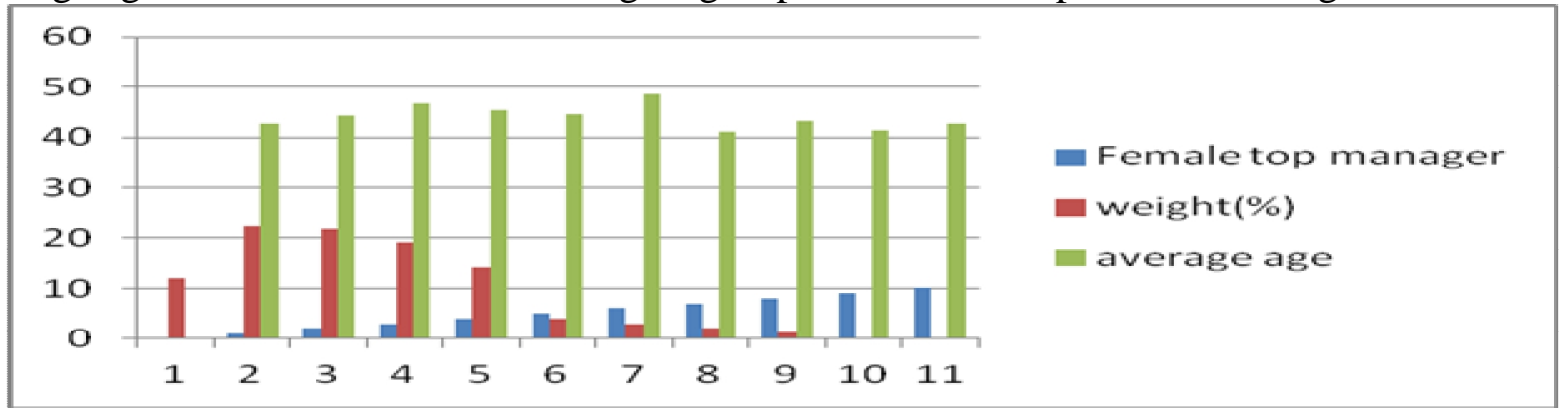

Figure 1. Distribution of female senior manager and average age

Figure 2 shows the distribution of female members in board of directors. The board of directors, including president, executive director, independent director and secretary of the board, is essential for company governance, thus the distribution of female proportion reveals how women are represented in company decision making. Figure 2 indicates that most companies have 2 female director members with the proportion of $24 \%$, followed by 1 female $(21 \%)$ and 0 female (17\%). There are 35 companies with no single female members inside board of directors. Basically the amount of companies decreases by the increasing number of female board members.

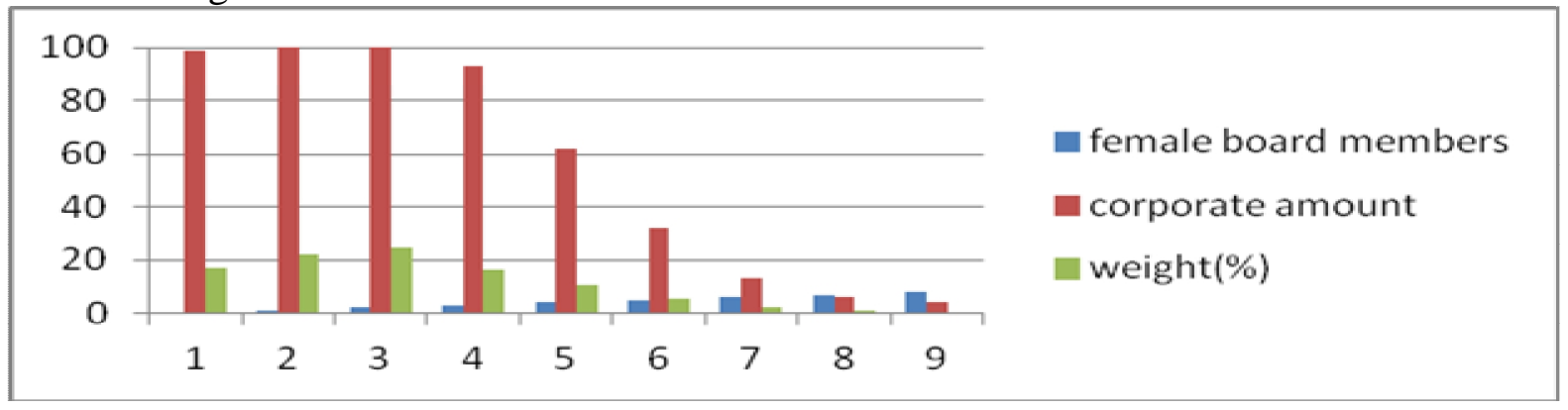

Figure 2. Distribution of female members in board of directors

Figure 3 shows the distribution of female senior managers' age. In this study we classified ages into 5 groups, which are under 30, 30 to 40, 40 to 50, 50 to 60 and over 60. As we can see from figure 3, 
most female senior managers are in their forties (share of 52\%), followed by the age of thirties (share of $22 \%$ ) and fifties (share of 14\%). Female senior managers of age over 60 take up the least share of $0.9 \%$.

Figure 4 shows education background of female senior managers. We set education background in five groups, from high to low, doctor degree, master degree, undergraduate, college and weak background. Based on the education system in China, here college group stands for vocational education or equivalent. Weak background stands for those with low or none education background. Most female senior managers in sample data have bachelor degree of which $38.4 \%$ undergraduates. $24.4 \%$ of female senior managers have master degree and only $3.3 \%$ doctor degree. In sum, $66 \%$ of female senior managers in sample companies are university graduate level or above. $32 \%$ of female senior managers have college background and only $1.7 \%$ has weak education background. Education background of female senior managers presents a normal distribution indicating that university experience is demanding and essential for business women.

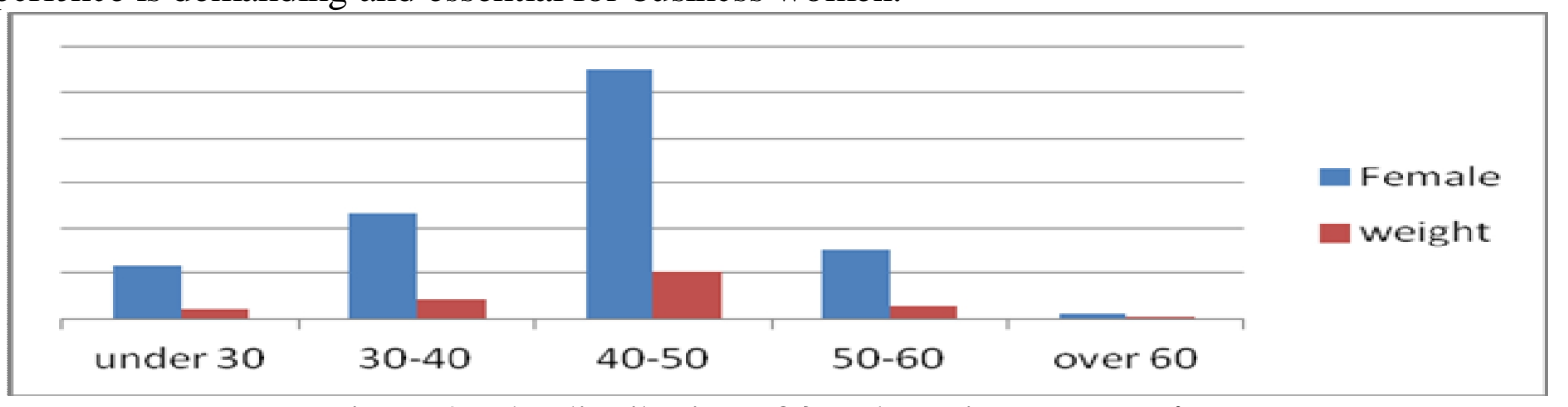

Figure 3. The distribution of female senior managers' age

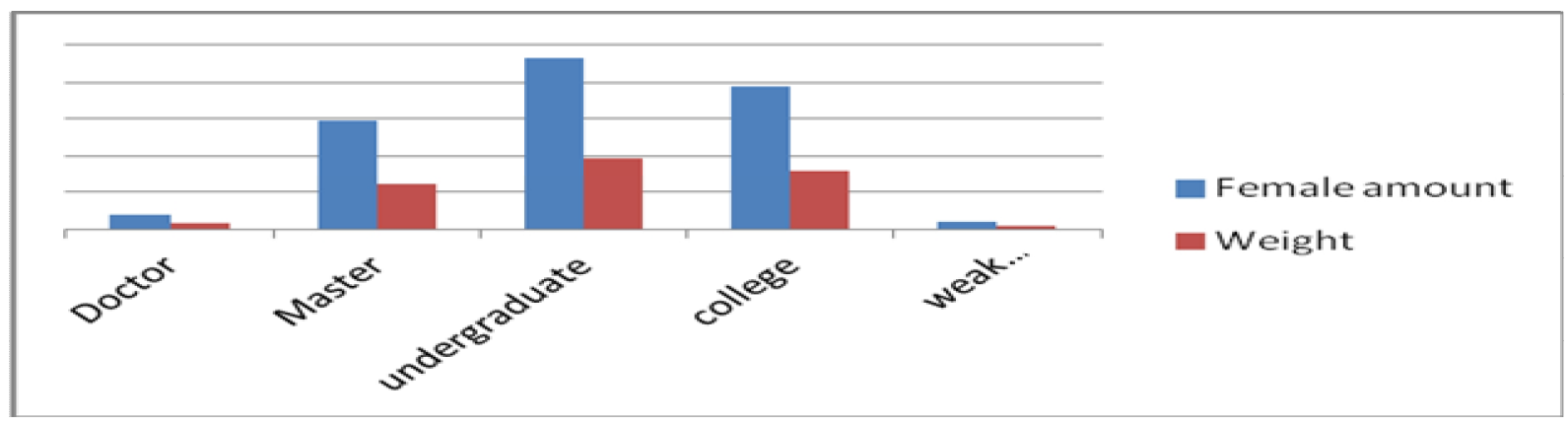

Figure 4. Education background of female senior mangers

\section{Conclusion}

This study sampling investigated 200 China listed companies to explore the pattern of female senior business leadership in e-commerce industry. The results reveal that despite the highest proportion of female senior positions in the world, the gender specific issue indeed exists within e-commerce companies' top-level management. There are $75 \%$ sample companies held no more than 3 female senior managers, and this percentage is $97 \%$ for female members in board of directors, indicating a large gap from being balance in senior management leadership. Female senior managers in sample companies have an average age of forties and well educated. These findings imply that higher education help empower business female to get important position. Age issue is proved to be related with various factors of company governance, in this result, female with middle age are preferred for senior manager. This could be explained that women with proper education degree and years of manage experiences are advantageous for career promotion.

This study analyzes and discusses the distributions of female senior leadership by categories of position, age, and education background to plot a general impression of female managers. Thus make a better understanding and draw attention to glass ceiling problems at the highest levels within China listed companies of e-commerce industry. As surveyed by Lockwood that companies which have high proportion of female senior managers make better profit margin [7]. It is suggested that measurements 
be taken to diminish gender differences in high-level management team. For instance, e-commerce companies should be encouraged to provide more senior positions for female; government should make policies for female business owner to help start-up and operate a e-commerce company; female managers should be more informed about financial and operation information. Finally, this study hoped that the research results can be beneficial to managers, researchers, or governments, and contributed to relevant studies and future researches as reference.

\section{References}

[1] Thornton, G. Women in senior management: setting the stage for growth, Grant Thornton International Business Report 2014. (2014)

[2] Commission, U. S. G. C. A Solid Investment: Making Full Use of the Nation's Human Capital (Final Report of the Commission). Washington, DC: U.S: Government Printing Office. (1995)

[3] Brewis, J., \& Linstead, S. Gender and management. Management: A Critical Text, (1999) 48-81.

[4] Bertrand, M., \& Hallock, K. F. The gender gap in top corporate jobs: National Bureau of Economic Research. (2000).

[5]Chu, P. The Characteristics of Chinese Female Entrepreneurs: Motivation and Personality. Journal of Enterprising Culture, 08(01) (2000).

[6] Pascall, G., Parker, S., \& Evetts, J. Women in Banking Careers—a Science of Muddling Through? Journal of Gender Studies, 9(1), (2000) 63-73.

[7] Lockwood, N. The glass ceiling: Domestic and international perspectives: Society for Human Resource Management. (2004). 